
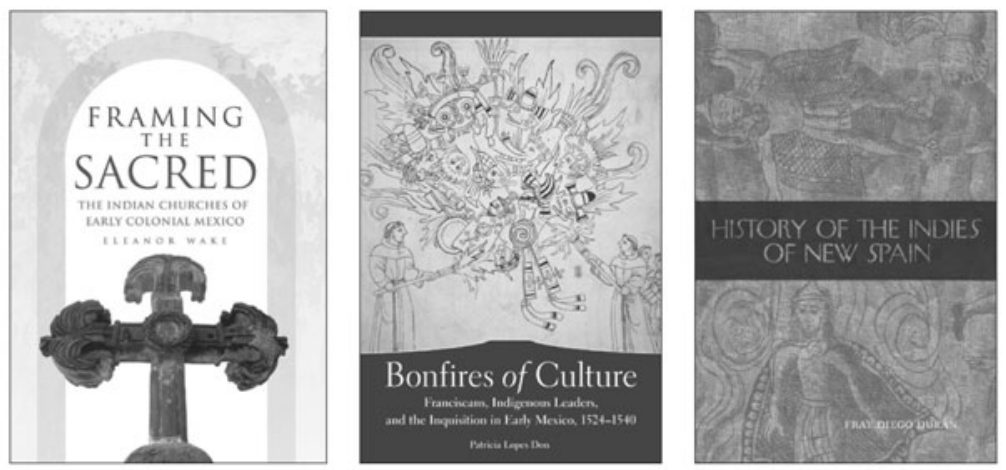

FRAMING THE SACRED

The Indian Churches of Early Colonial Mexico

By Eleanor Wake

$\$ 65.00$ HARDCOVER - 368 PAGES, 238 B\&W ILLUS, 26 COLOR PHOTOS

Christian churches erected in Mexico during the early colonial era represented the triumph of European conquest and religious domination. Or did they? Building on recent research that questions the "cultural" conquest of Mesoamerica, Eleanor Wake shows that colonial Mexican churches also reflected the beliefs of the indigenous communities that built them. Wake also examines how the art and architecture of Mexico's religious structures reveals the indigenous people's own decisions regarding the conversion program and their accommodation of the Christian message.

\title{
BONFIRES OF CULTURE
}

Franciscans, Indigenous Leaders, and the Inquisition in Early Mexico, 1524-1540

By Patricia Lopes Don

$\$ 34.95$ HARDCOVER - 280 PAGES, 5 B\&W ILLUS.

In their efforts to convert indigenous peoples, Franciscan friars brought the Spanish Inquisition to early-sixteenth-century Mexico. Patricia Lopes Don now investigates these trials to offer an inside look at this brief but consequential episode of Spanish methods of colonization, providing a fresh interpretation of an early period that has remained too long understudied.

\section{HISTORY OF THE INDIES OF NEW SPAIN}

By Fray Diego Durán

$\$ 39.95$ PAPERBACK $\cdot 642$ PAGES

A sixteenth-century Dominican friar, Fray Diego Durán was born in Spain but raised in Mexico. His firsthand experience of Mexican culture and fluency in the Nahuatl language made him one of the most sympathetic and knowledgeable of the missionary-ethnographers. His History of the Indies of New Spain, newly translated by Doris Heyden, is a vivid evocation of the Aztec world before the Spanish conquest.

UNIVERSITY OF OKLAHOMA PRESS
2800 VENTURE DRIVE

NORMAN, OKLAHOMA 73069

TEL 8006277377 • OUPRESS.COM 


\section{CAMBRIDGE}

\section{Outstanding Scholarship from Cambridge}

\section{Cambridge Studies in Comparative Politics}

Latin America
Party Systems
HerBERT KITSCHELT,
KIRK A. HAWKINs,
JuAN PABLO LUNA,

GUILERMO RosAs, AND

EUZABEtH J. ZECHMEISTER

\$90.00: Hb: 978-0-521-11495-0

\$34.99: Pb: 978-0-521-13266-4: $416 \mathrm{pp}$.

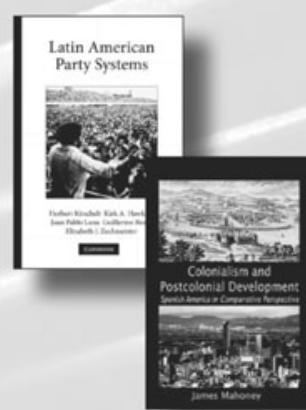

Colonialism and

Postcolonial

Development

Spanish America in

Comparative Perspective

JAMES MAHONEY

\$85.00: Hb: $978-0-521-11634-3$

\$24.99: Pb: $978-0-521-13328-9$ :

$424 \mathrm{pp}$.

The Cost of Courage in Aztec Society

Essays on Mesoamerican Society and Culture

Inga Clendinnen

\$85.00: Hb: 978-0-521-51811-6

\$24.99: Pb: 978-0-521-73207-9:

$270 \mathrm{pp}$.
In Search of an Inca Identity and Utopia in the Andes Alberto Flores Galindo

New Approaches to the Americas \$75.00: Hb: 978-0-521-59134-8 \$22.99: Pb: 978-0-521-59861-3. $250 \mathrm{pp}$.

\section{A History of the Khipu}

Galen BRokAW

Cambridge Latin American Studies \$90.00: Hb: 978-0-521-19779-3: $336 \mathrm{pp}$.

Social Memory in Ancient and Colonial Mesoamerica Amos Megged

\$95.00: Hb: 978-0-521-11227-7: $325 \mathrm{pp}$.

Decentralization and Subnational Politics in Latin America

Tulia G. Falleti

\$85.00: Hb: 978-0-521-51679-2 \$26.99: Pb: 978-0-521-73635-0: $312 \mathrm{pp}$.

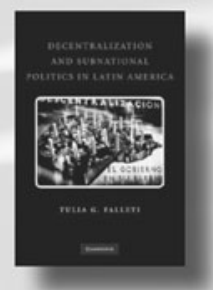

Presidents, Parties, and Prime Ministers How the Separation of Powers Affects Party Organization and Behavior

David SAMUels AND

MATTHEW SHugaRT

\$90.00: Hb: 978-0-521-86954-6 \$27.99: Pb: $978-0-521-68968-7$ : $270 \mathrm{pp}$.

\section{Social Capital in} Developing Democracies Argentina and Nicaragua

LESLIE E. ANDERSON

S85.00: Hb: 978-0-521-19274-3

\$27.99: Pb: 978-0-521-14084-3: $320 \mathrm{pp}$.

\section{Venezuela's}

Chavismo and Populism in Comparative Perspective

KIRK A. HaWKINS

\$80.00: Hb: 978-0-521-76503-9: $312 \mathrm{pp}$.

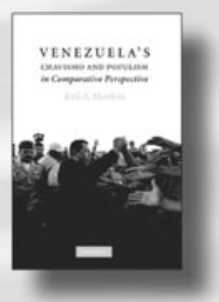

Cultures of Legality Judicialization and Political Activism in Latin America Edited by Javier Couso, Alexandra Huneeus, and RACHEL SIEDER

Cambridge Studies in Law and Society \$85.00: Hb: 978-0-521-76723-1: $312 \mathrm{pp}$.

Latin American Development Priorities

Costs and Benefits EDITED BY BJøRN LOMBORG \$115.00: Hb: 978-0-521-76690-6 $\$ 50.00: \mathrm{Pb}: 978-0-521-74752-3$ : $724 \mathrm{pp}$.

Prices subject to change 


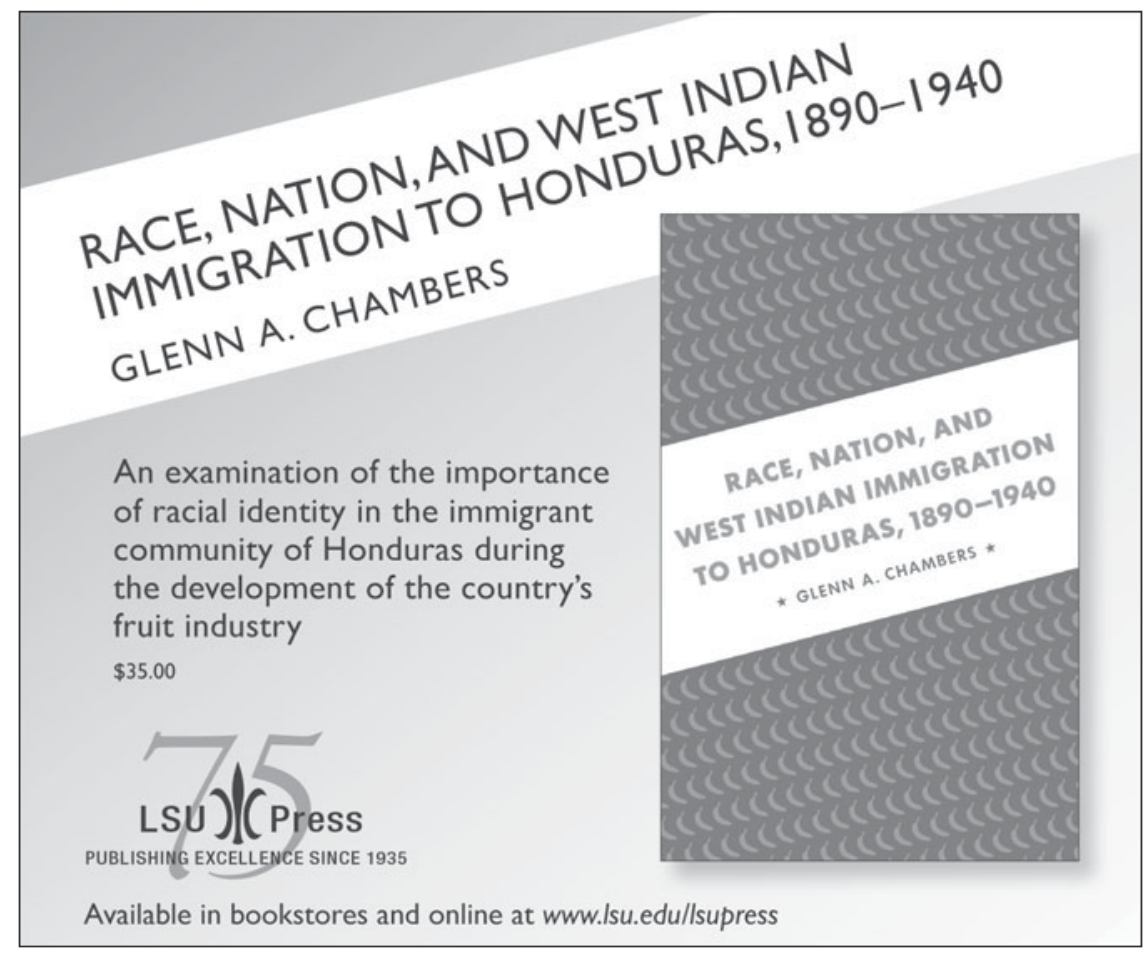




\section{NEW}

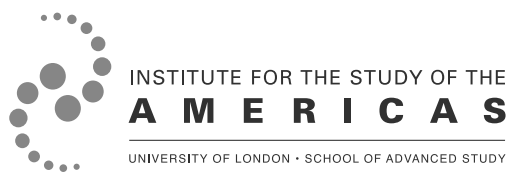

World Crisis Effects on Social Security in Latin America and the Caribbean: Lessons and Policies

Carmelo Menotaso.
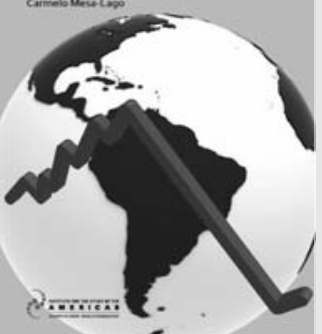

\section{World Crisis Effects on} Social Security in Latin America and the Caribbean:

\section{Lessons and Policies} by Carmelo Mesa-Lago

This book, by the leading social policy analyst of Latin America, evaluates the effects of the global financial crisis on the region's social security.

Carmelo Mesa-Lago takes a comparative approach to the analysis of pensions, health care and social assistance in 25 Latin American and Caribbean

countries. The analysis, supported by a wealth of data, explores the key themes necessary to understand how Latin America's social security systems are affected by the global crisis: these include the impact of previous crises; the strengths and weaknesses of social security prior to the current slump; the adverse social effects of the recession which have already occurred as well as the potential ones; and the counter-cyclical measures taken. It also extracts lessons and recommends policies to cope with the negative effects of the crisis and to strengthen social protection in the future.

ISBN 9781900039970

\section{RECENT TITLES}

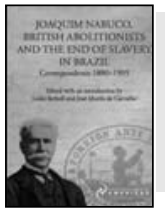

Joaquim Nabuco, British Abolitionists and the End of Slavery in Brazil

edited by Leslie Bethell and Jose Murilo de Carvalho

ISBN 9781900039956

The Political Economy of the Public Budget in the Americas

edited by Diego Sánchez-Ancochea and Iwan Morgan

ISBN 9781900039949

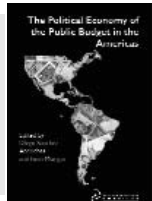

Institute for the Study of the Americas

www.americas.sas.ac.uk

americas@sas.ac.uk 


\section{CAMBRIDGE}

\section{JOURNALS}

\section{NEW FOR 2010}

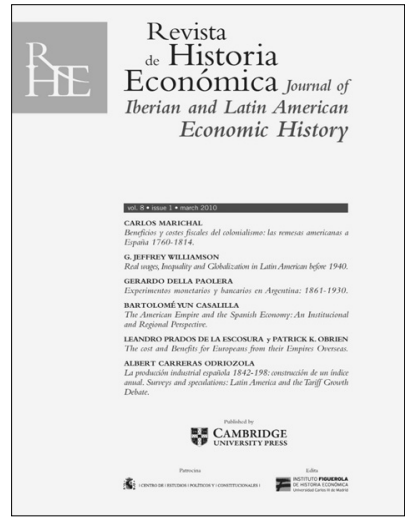

Revista de Historia Económica Journal of Iberian and Latin American Economic History is available online at http://journals.cambridge.org/rhe

To subscribe contact Customer Services

in Cambridge:

Phone +44 (0)1223 326070

Fax +44 (0)1223 325150

Email journals@cambridge.org

in New York:

Phone +1 (845) 3537500

Fax +1 (845) 3534141

Email

subscriptions_newyork@cambridge.org

\section{Revista de Historia Económica - Journal of Iberian and Latin American Economic History}

Published for Instituto Figuerola de Historia y Ciencias Sociales, Universidad Carlos III de Madrid

\section{Editors}

Luis Bértola, Universidad de la República, Montevideo, Uruguay

Alan Dye, Columbia University, USA

Antonio Tena, Universidad Carlos III de Madrid, Spain

Revista de Historia Económica - Journal of Iberian and Latin American Economic History (RHE-JILAEH) welcomes contributions with comparative approaches, especially those that include a wide geographical or global coverage. The journal will promote the presentation of new topics, ideas and perspectives from the different social sciences, notably new historical and economic methods.

\section{Price information is available at http://journals.cambridge.org/rhe}

\section{Free email alerts}

Keep up-to-date with new material - sign up at http://journals.cambridge.org/alerts

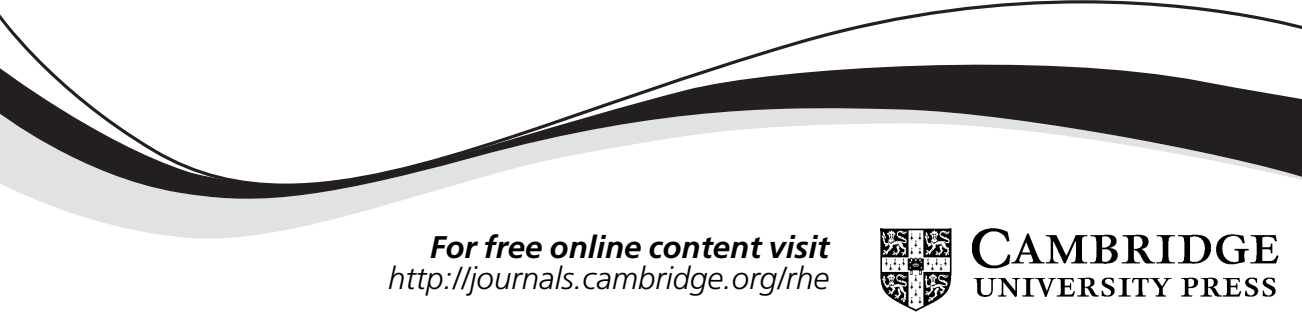




\section{CAMBRIDGE}

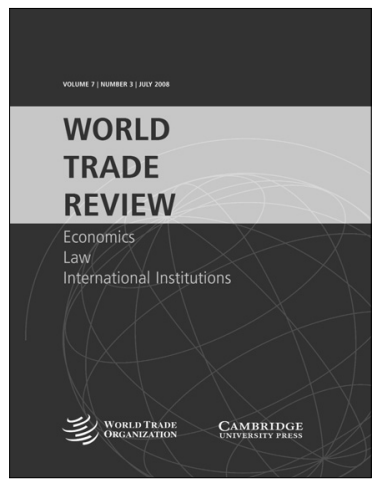

World Trade Review

is available online at:

http://journals.cambridge.org/wtr

To subscribe contact

Customer Services

in Cambridge:

Phone +44 (0)1223 326070

Fax $+44(0) 1223325150$

Email journals@cambridge.org

\section{in New York:}

Phone +1 (845) 3537500

Fax +1 (845) 3534141

Email

subscriptions_newyork@cambridge.org

\section{WORLD \\ TRADE \\ REVIEW}

\section{Editor}

Douglas A. Irwin, Dartmouth College, Hanover, USA

The World Trade Review was established at the initiative of the Secretariat of the World Trade Organization (WTO) in close cooperation with Cambridge University Press. It is an independent journal - the Editor and all but one member of the Editorial Board are drawn from university faculties - that includes articles written from economic, legal, political and inter-disciplinary perspectives on issues of relevance to the multilateral trading system. The journal also includes shorter articles seeking to rebut or challenge published papers.

\section{Price information is available at: http://journals.cambridge.org/wtr}

Free email alerts
Keep up-to-date with new material - sign up at
http://journals.cambridge.org/alerts

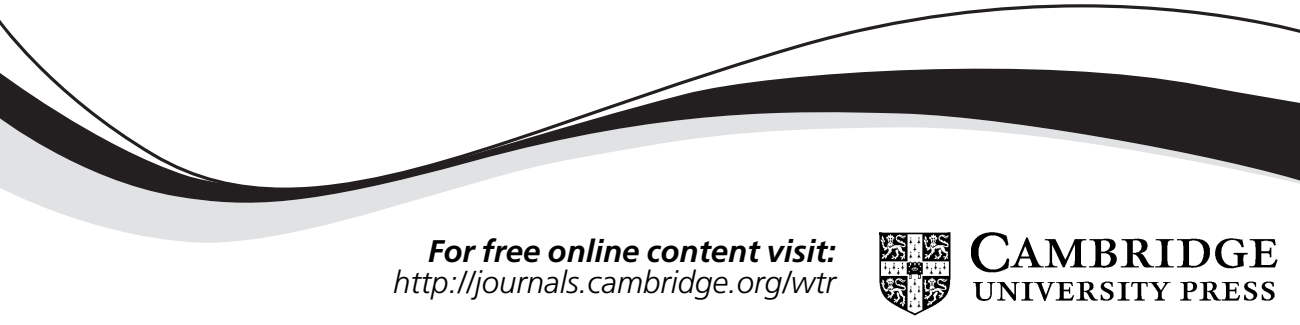




\section{CAMBRIDGE}

\section{JOURNALS}

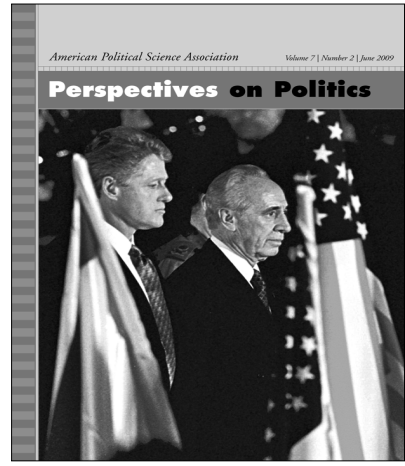

Perspectives on Politics

is available online at:

http;/ljournals.cambridge.org/pps

To subscribe contact

Customer Services

in Cambridge:

Phone +44 (0)1223 326070

Fax $+44(0) 1223325150$

Email journals@cambridge.org

\section{in New York:}

Phone +1 (845) 3537500

Fax +1 (845) 3534141

Email

subscriptions_newyork@cambridge.org

\section{Perspectives on Politics}

Published for the American Political Science Association and sold ONLY as part of a joint subscription with American Political Science Review and PS: Political Science \& Politics.

\section{Editor}

Jeffrey C. Isaac, Indiana University, USA

Perspectives on Politics is of broad interest to scholars, professional political scientists, political analysts, policy makers, and the informed public. Essays synthesize and extend significant research and developments in all dimensions of political science scholarship. The journal connects research findings, conceptual innovations, or theoretical developments to real problems of politics.

\section{Price information is available at: http://journals.cambridge.org/pps}

Free email alerts
Keep up-to-date with new material - sign up at
http://journals.cambridge.org/alerts

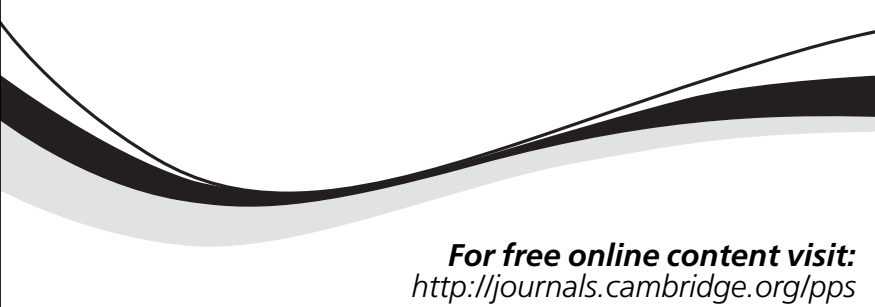




\section{CAMBRIDGE}

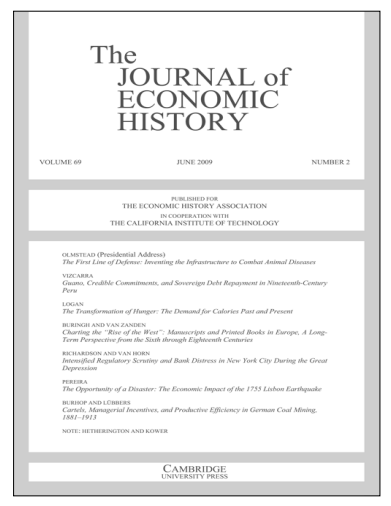

The Journal of Economic History is available online at:

htt;:/ljournals.cambridge.org/jeh

To subscribe contact

Customer Services

in Cambridge:

Phone +44 (0)1223 326070

Fax +44 (0)1223 325150

Email journals@cambridge.org

\section{in New York:}

Phone +1 (845) 3537500

Fax +1 (845) 3534141

Email

subscriptions_newyork@cambridge.org

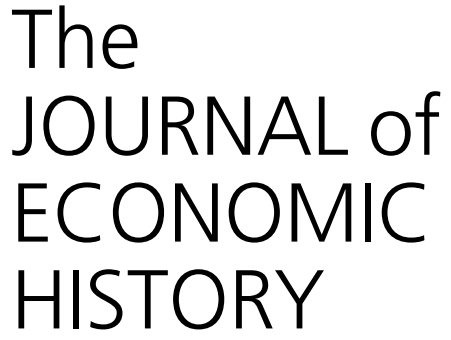

Published for the Economic History Association

\section{Editors}

Philip T. Hoffman, California Institute of Technology, USA Price V. Fishback, University of Arizona, USA

The Journal of Economic History is devoted to the interdisciplinary study of history and economics, and is of interest not only to economic historians but to social and demographic historians, as well as economists in general. The journal has broad coverage, in terms of both method and geographic scope.

\section{Price information is available at: http://journals.cambridge.org/jeh}

\section{Free email alerts}

Keep up-to-date with new material - sign up at http://journals.cambridge.org/alerts 


\section{CAMBRIDGE}

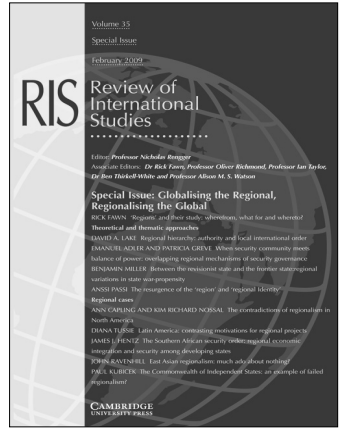

Review of International Studies is available online at:

http://journals.cambridge.org/ris

To subscribe contact

Customer Services

in Cambridge:

Phone +44 (0)1223 326070

Fax +44 (0)1223 325150

Email journals@cambridge.org

\section{in New York:}

Phone +1 (845) 3537500

Fax +1 (845) 3534141

Email

subscriptions_newyork@cambridge.org

\section{Review of International Studies}

Published for the British International Studies Association

\section{Editor}

Nick Rengger, University of St Andrews, UK

Review of International Studies serves the needs of scholars in international relations and related fields such as politics, history, law, and sociology. The Review publishes a significant number of high quality research articles, review articles which survey new contributions to the field, a forum section to accommodate debates and replies, and occasional interviews with leading scholars.

\section{Price information is available at: http://journals.cambridge.org/ris}

\section{Free email alerts}

Keep up-to-date with new material - sign up at http://journals.cambridge.org/alerts 


\section{NOTES FOR CONTRIBUTORS}

\section{Editorial Policy}

The Journal of Latin American Studies is published four times a year, in February, May, August and November. Its editorial offices are located at the Institute for the Study of the Americas, University of London. The editorial board comprises area studies specialists based in the United Kingdom from all the principal social science disciplines, including history.

The Journal aims to publish recent research in the field of Latin American studies in economics, geography, politics, international relations, sociology, social anthropology and history. Articles on literature and the arts are not normally included, but the editors are pleased to consider contributions in the field of intellectual and cultural history. Articles with an inter-disciplinary approach are particularly welcome.

\section{Manuscript Submission}

Articles submitted to the Journal should be original contributions. They should not be under consideration by another journal, nor have been published or be awaiting publication elsewhere. Translations of articles that have already been published will not be accepted. If an author is publishing a closely related article elsewhere, this fact should be stated in a cover note to the editors. Authors of articles published in the Journal assign copyright to Cambridge University Press (with certain rights reserved) and will receive a copyright assignment form for signature on acceptance of their paper.

Articles must be no longer than 12,000 words, including footnotes, tables etc. The Journal is published in English, but articles may also be submitted in Spanish or Portuguese for peer review; if accepted for publication, the responsibility for translating articles rests with the author. The Journal's preference is that manuscripts should be submitted electronically as a Word document, with double spacing throughout and margins of at least one inch all round. All pages must be numbered consecutively. In order to ensure the anonymity of the reviewing process, care should be taken to ensure that any references which might identify the author are removed from the text. The title page should be separate from the main body of the text and include the author's name, academic post and institutional affiliation, the title of the article, and brief acknowledgements. An abstract of no more than 100 words, together with a list of key words, should appear at the beginning of the article.

The Journal publishes commissioned book reviews in each issue. Not all books received can be reviewed, and editorial policy gives preference to reviews of books regarded as being of major importance for the disciplines covered by the Journal. Unsolicited reviews cannot be considered.

Contributors are responsible for obtaining permission to reproduce any material for which they do not own copyright, to be used in both print and electronic media, and for ensuring that the appropriate acknowledgements are included in their manuscript.

Articles for consideration and all editorial correspondence should be addressed to The Editors, Journal of Latin American Studies, Institute for the Study of the Americas, 31 Tavistock Square, London WC1H 9HA, UK, or sent to jlas@sas.ac.uk.

\section{Proofs}

Proofs of accepted articles will be sent to authors as pdf files for checking and correction of typesetting errors. Typographical or factual errors only may be changed at proof stage. The publisher reserves the right to charge authors for correction of non-typographical errors.

\section{Offprints}

Contributors will receive a pdf file of their article.

This issue has been printed on FSC-certified paper and cover board. FSC is an independent, non-governmental, not-for-profit organisation established to promote the responsible management of the world's forests. Please see www.fsc.org for information.

\section{CAMBRIDGE UNIVERSITY PRESS}

The Edinburgh Building, Cambridge Св2 8RU, United Kingdom

32 Avenue of the Americas, New York, NY IOOI3-2473, USA

477 Williamstown Road, Port Melbourne, vic 3207, Australia

Ruiz de Alarcón I3, 280I4 Madrid, Spain

Dock House, The Waterfront, Cape Town 80or, South Africa

Printed at the University Press, Cambridge, UK. 


\section{Journal of Latin American Studies}

volume 42: part 2: May 2010

\section{Articles}

231 Brazilian Abolitionism, Its Historiography, and the Uses of

Political History

JEFFREY D. NEEDELL

263 Cabaretistas and Indias Bonitas: Gender and Representations of Mexico in the Americas during the Cárdenas Era

AMELIA M. KIDDLE

293 Re-Mapping the Nation: Cartography, Geographical Knowledge and Ecuadorean Multiculturalism

SARAH A. RADCLIFFE

325 Segmented Party-Voter Linkages in Latin America: The Case of the UDI JUAN PABLO LUNA

\section{Commentary}

357 Democracy without Parties? Some Lessons from Peru JOHN CRABTREE

Book Reviews

447 Books Received

Cambridge Journals Online For further information about this journal please go to the journal website at: journals.cambridge.org/las

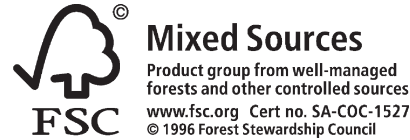

CAMBRIDGE UNIVERSITY PRESS 